\title{
Deuteronomy in the Pentateuch, Hexateuch, and the Deuteronomistic History
}

Ed. by Konrad Schmid and Raymond F. Person, Jr.

[Das Deuteronomium im Pentateuch, Hexateuch und das Deuteronomistische Geschichtswerk.]

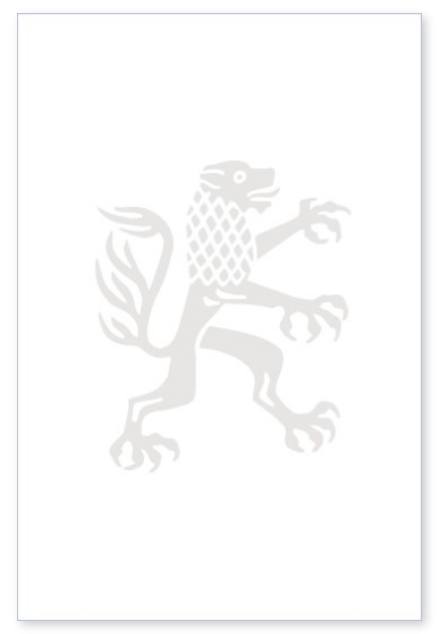

2012. IX, 179 Seiten. FAT II 56

ISBN 978-3-16-152423-3

DOI 10.1628/978-3-16-152423-3

eBook PDF $54,00 €$

ISBN 978-3-16-151008-3

fadengeheftete Broschur 54,00€
Veröffentlicht auf Englisch.

Der bisher herrschende Konsens über die literarhistorische Verankerung des Deuteronomiums im Pentateuch wird in der neueren Forschung vermehrt in Frage gestellt. Das Deuteronomium spielt in diesen Diskussionen aufgrund seiner Position im Kanon eine wichtige Rolle. Herkömmlich wurde davon ausgegangen, dass die Quelle D im Pentateuch in erster Linie, wenn nicht sogar ausschließlich im Deuteronomium zu finden sei und dieses wiederum der Kern des Deuteronomistischen Geschichtswerkes sei. In jüngster Zeit diskutiert die Forschung über D-Anteile im literarischen Kontext vor und nach dem Deuteronomium, während andere die zentrale Bedeutung von D für die Entstehung des sogenannten Deuteronomistischen Geschichtswerkes in Frage stellen. Dieser Band vereinigt unterschiedliche Stimmen zu den Debatten über die Rolle des Deuteronomiums in seinen literarischen Kontexten von Genesis bis 2. Könige.

Inhaltsübersicht

Konrad Schmid and Raymond F. Person, Jr.: Introduction - Reinhard G. Kratz: The Headings of the Book of Deuteronomy Jeffrey Stackert: Mosaic Prophecy and the Deuteronomic Source of the Torah - Sandra L. Richter: Placing the Name, Pushing the Paradigm: A Decade with the Deuteronomistic Name Formula - Christophe Nihan: The Literary Relationship between Deuteronomy and Joshua: A Reassessment - Cynthia Edenburg: Joshua 9 and Deuteronomy; an Intertextual Conundrum: the Chicken or the Egg? - Juha Pakkala: Deuteronomy and 1-2 Kings in the Redaction of the Pentateuch and Former Prophets Konrad Schmid: Deuteronomy within the 'Deuteronomistic Histories' in Genesis-2 Kings

Raymond F. Person Keine aktuellen Daten verfügbar.

Konrad Schmid Born 1965; professor of Old Testament and Ancient Judaism at the Faculty of Theology at the University of Zürich, Switzerland.

https://orcid.org/0000-0002-8968-2604

Jetzt bestellen:

https://mohrsiebeck.com/buch/deuteronomy-in-the-pentateuch-hexateuch-and-the-deuteronomistic-history9783161524233?no_cache=1

order@mohrsiebeck.com

Telefon: +49 (0)7071-923-17

Telefax: +49 (0)7071-51104 